\title{
Ladinian palynofloras in the Norwegian-Danish Basin: a regional marker reflecting a climate change
}

\author{
Sofie Lindström, Henrik Vosgerau, Stefan Piasecki, Lars Henrik Nielsen, Karen Dybkjær \\ and Mikael Erlström
}

The Triassic - lower Cretaceous sedimentary succession of the Norwegian-Danish Basin has for a long time been of exploration interest, and numerous studies have been carried out. However, high-resolution correlation within the basin remains necessary, especially between the Danish and Norwegian parts of the basin. A variety of litho- and biostratigraphic schemes have been applied to the succession over the years, but lack of consistency in terminology has often led to confusing interpretations of the geological development. In this study a sequence stratigraphic scheme has been developed for the Danish Basin and a compiled palynological event stratigraphy is applied to a number of wells connecting the Danish and Norwegian parts of the basin and new marker horizons are identified. One of the aims of this study is to reach consistency in order to facilitate correlation within the basin and we also emphasise the recognition of a potentially important mid-Triassic event in the basin.

\section{Geological setting}

The intracratonic Permian-Cenozoic Norwegian-Danish Basin is bounded to the south by the Ringkøbing-Fyn High and to the north by the strongly faulted Sorgenfrei-Tornquist Zone (Fig. 1). The basin was formed by Late Carboniferous - Early Permian crustal extension followed by thermal sagging, local faulting and salt tectonics. The syn-rift succession consists of Rotliegendes volcaniclastic rocks, alluvial conglomerates and sandstones as well as lacustrine mudstones. The overlying Zechstein-Cenozoic post-rift succession consists of two major sequences separated by an early Middle Jurassic unconformity that reflects regional uplift and erosion (Nielsen 2003). The lower sequence comprises Zechstein salt, Triassic sandstones, mudstones, marls and carbonates and Lower Jurassic claystones, while the upper sequence encompasses Middle Jurassic - Lower Cretaceous clastic rocks,

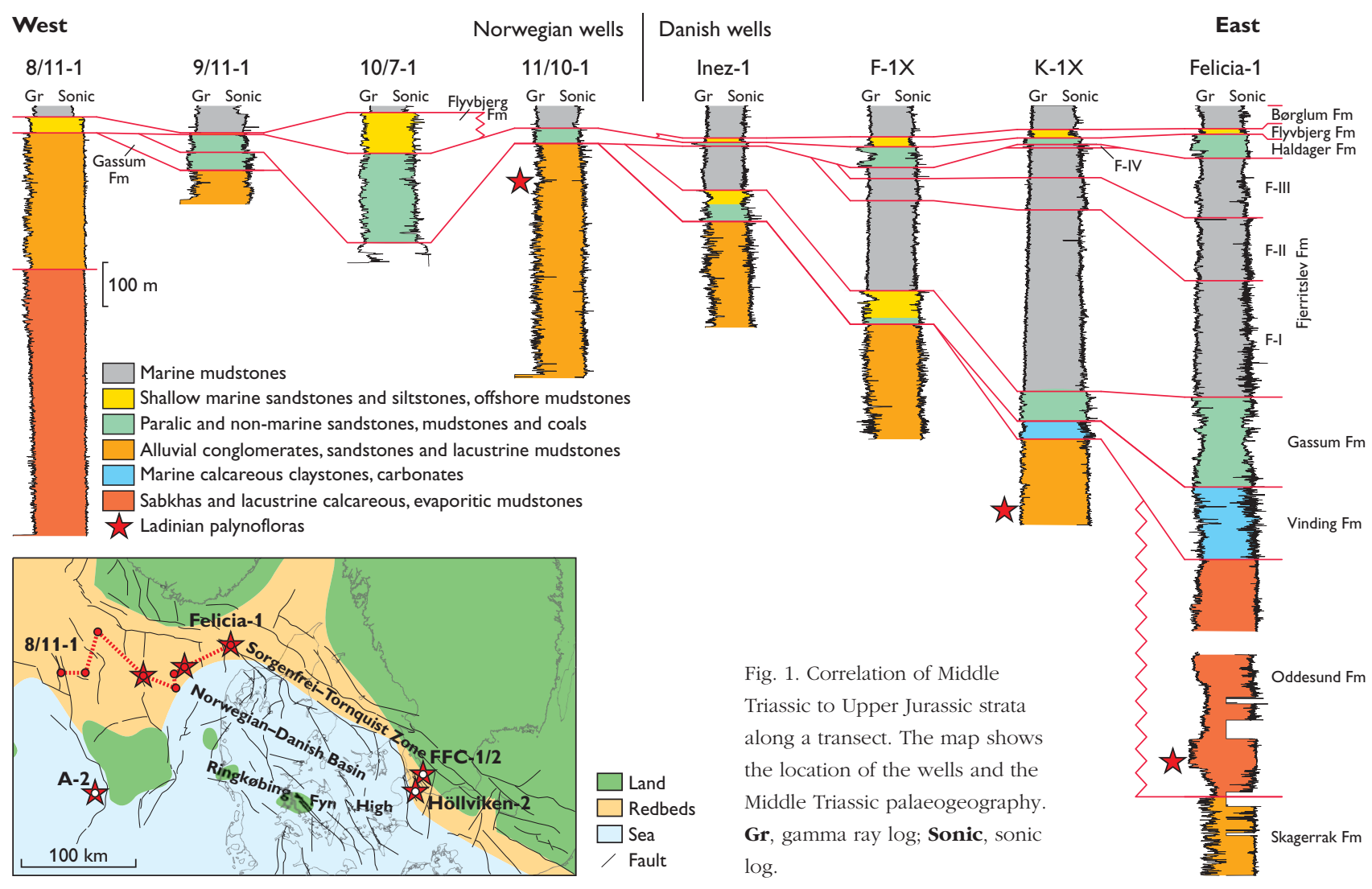




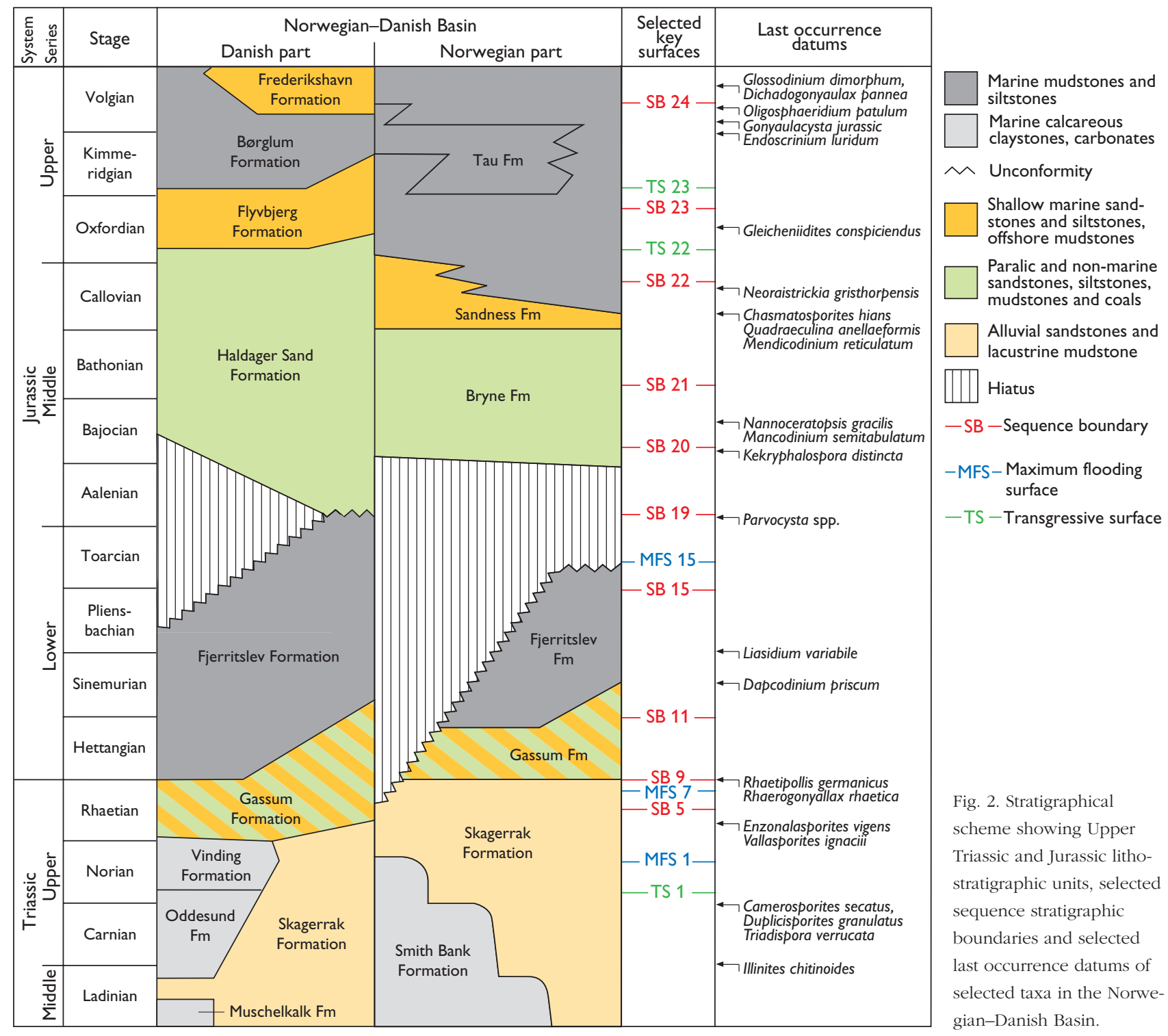

Upper Cretaceous Chalk and Cenozoic clastic rocks. Large parts of the lower sequence are difficult to date accurately by biostratigraphy owing to the predominantly continental strata deposited during a hot and arid climate, whereas the upper sequence is dominated by marine fossiliferous deposits, which are easier to date.

\section{The investigated succession and the stratigraphic approach}

The principal reservoir rocks and potential source rocks of the basin were formed during Late Triassic - Late Jurassic times (Petersen et al. 2008). Different lithostratigraphic terminologies are used for the Norwegian and Danish areas (Fig. 2). An inconsistent mixture of lithostratigraphic names from both Norwegian and Danish schemes is commonly used by the operators in well reports, and in some cases, lithostrati- graphic names normally applied to units in the Norwegian Central Graben further contribute to the confusion. A robust sequence stratigraphic scheme established in the Danish Basin by Nielsen (2003) and a compiled palynostratigraphic event scheme are applied to a number of wells (Felicia-1, K-1, F-1, Inez-1, 11/10-1, 10/7-1, 9/11-1 and 8/11-1) situated along an E-W trending transect from the Fjerritslev Fault NW of Jylland to the border of the Norwegian Central Graben (Fig. 1). Based on characteristic well-log patterns supported by lithological descriptions from well reports, formation tops and sequence stratigraphic surfaces were identified and integrated with palynological events identified in this study. The latter events are based on established spore-pollen and dinoflagellate cyst stratigraphies for the Triassic - Early Cretaceous of western Europe. Selected important palynostratigraphic events and sequence stratigraphic surfaces are shown in Fig. 2. 
The results of the correlation show that lithostratigraphic units and key sequence stratigraphic surfaces can be followed across the Danish and Norwegian areas indicating that the general depositional development along the transect largely follows the pattern described by Nielsen (2003). Hence, the sequence stratigraphic and lithostratigraphic schemes established for the Danish part were successfully applied to the Norwegian wells, as exemplified in Figs 1, 2.

However, the lack of readily recognisable sequence stratigraphic key surfaces and biostratigraphic events within the Middle - Upper Triassic succession is a major problem for reliable stratigraphic analyses.

\section{The Middle Triassic - an unsuitable climate for palynomorph preservation}

During the Middle Triassic the Norwegian-Danish Basin was situated around $35^{\circ} \mathrm{N}$. The arid to semi-arid conditions that had prevailed during the Early Triassic continued, as signified by mainly fluvial and lacustrine, heterogeneous, siliciclastic rocks of the Skagerrak Formation (Michelsen \& Clausen 2002). Marine calcareous mudstones and carbonates of the Muschelkalk Formation in the North German Basin expanded northwards during a transgressive event in the Anisian to early Ladinian (Michelsen \& Clausen 2002). Arid to semi-arid climatic conditions continued during early Late Triassic times, with deposition of variegated, calcareous, anhydritic and pyritic mudstones in sabkhas and ephemeral lakes. In the deep central part of the basin more permanent lakes were established. The deposits are included in the Oddesund (Danish area) and Smith Bank (Norwegian area) formations. Towards the basin margins in the north and north-east these deposits pass into alluvial fans and fluvial sediments of the Skagerrak Formation. The combination of large lateral variations in depositional environment and the absence of extensive marine-flooding surfaces and marked unconformities hinder identification of reliable and regional sequence stratigraphic key surfaces.

Whereas Middle to lower Upper Triassic successions of the Arctic, Alpine and Tethys regions show evidence of fairly rich and diverse vegetation, the pre-Rhaetian Triassic redbeds of the Norwegian-Danish Basin only contain sparse palynomorphs. However, this does not necessarily mean that there were no plants growing in the area at the time of deposition. Most arid areas today host some vegetation adapted to such a hostile climate, but conditions for preservation of palynomorphs are generally poor due to oxidation of the sediments. Nevertheless, the present study indicates that during a restricted interval in the latest Middle Triassic the area hosted a relatively rich vegetation and the climatic conditions in the area were better suited for palynomorph preservation.

\section{Ladinian spore-pollen floras}

Well-preserved, typical Middle Triassic palynofloras were found in ditch cuttings from the lowermost part of the Oddesund Formation in the Felicia- 1 well, and in the lower part of the Skagerrak Formation in K-1 and 11/10-1. These assemblages are distinguished from caved Rhaetian-Cretaceous material by their generally darker colour. All the assemblages contain Illinites chitonoides, a pollen species that has a last appearance datum at the top of the Ladinian in northern Europe, and within the Carnian in the Arctic region (de Graziansky et al. 1998). The assemblage from Felicia-1 is dominated by the bisaccate pollen Ovalipollis ovalis /pseudoalatus, which has its first common appearance datum at the base of the late Ladinian (de Graziansky et al. 1998). In addition, members of Protodiploxypinus, e.g. P. fastidioides and P. macroverrucosus, and Triadispora, mainly T. crassa, T. plicata, T. verrucata, are common constituents of the palynofloras. The co-occurrence of Angustisulcites klausii, Kuglerina meieri, Podosporites amicus, Staurosaccites quadrifidus, Rimaesporites aquilonalis, Aratrisporites spp., Camerosporites secatus, C. verrucatus, Duplicisporites granulatus and Enzonalasporites vigens also suggests a late Ladinian age (de Graziansky et al. 1998; Schulz \& Heunisch 2005). The presence in Felicia-1 of the typical Triassic chlorococcalean coenobium Plaesiodictyon mosellanum with a known stratigraphical range from late Anisian to latest Norian indicates brackish to freshwater conditions.

In the easternmost parts of the Norwegian-Danish Basin comparable palynofloras are present in core samples from the Höllviken-2 well and two other wells in southern Sweden. The Höllviken-2 palynoflora is dominated by monolete (Aratrisporites spp.) and trilete (e.g. Calamospora spp. and Anapiculatisporites spp.) spores, but bisaccate pollen are also abundant and diverse. Both abundant Aratrisporites spores and species of Protodiploxypinus suggest a latest Muschelkalk - early Keuper (i.e. Ladinian) age, and this range is further limited to early Keuper by the presence of Retisulcites perforatus (last appearance datum in earliest Carnian), Nevesisporites lubricus, and Ovalipollis brutus. A banana-shaped acritarch, Dactylofusa sp., is present in the palynoflora from FCC-1.

Comparable palynofloral assemblages were found in well A-2 in the Danish Central Graben containing e.g. Aratrisporites saturni, Angustisulcites klausii, Illinites chitonoides, Triadispora spp., Protodiploxypinus fastidioides, P. granulatus, Protodiploxypinus spp., and Striatoabieites aytugii (Bertelsen 1975). Thus, typical Ladinian palynofloras appear to be present within a relatively restricted time interval along the northern margin of the mid-Triassic Muschelkalk sea. 


\section{Remarks on stratigraphy, environment and climate}

The Höllviken-2 assemblages are recorded in a succession of dark, fine-grained sediments (Maglarp-C member) with fossiliferous intervals containing fossil fish, ostracods and characean algae. Previous biostratigraphy based on the latter correlates the succession with late Muschelkalk to early Keuper, i.e. mainly of Ladinian age (Kozur 1974). The characean algae suggest limnic to possibly brackish environments, while the fish fauna vary from limnish-brackish (e.g. Paleobates spp.) to fully marine (e.g. Birgeria spp. and Hybodus spp.). The ostracods (Bairdia spp.) indicate warm, shallow littoral environments. Hence, the combined macrofossil evidence suggests a shallow marine environment with brackish to limnic lagoons behind the coast. The palynoflora recorded in the Höllviken-2 core supports a Ladinian age.

All the contemporaneous palynofloras described here contain several elements typical of warm and dry conditions. For instance, Aratrisporites is a common constituent in arid to semi-arid Triassic palynofloras worldwide. The parent plants, pleuromeiacean lycopsids, appear to have been opportunistic and saline-tolerant inhabitants of intertidal environments (Retallack 1975). The taeniate bisaccates, e.g. Lunatisporites and Striatoabieites, are generally regarded to have been produced by pteridosperms, and adapted to warm and dry conditions. The bisaccate pollen of Triadispora, Protodiploxypinus, Ovalipollis, Illinites and Staurosaccites, as well as the monosaccate pollen Enzonalasporites, and pollen of the Circumpolles group, i.e. Duplicisporites and Camerosporites, are all believed to come from conifers. The Circumpolles group is only recorded in some of the investigated assemblages. They are regarded as relatives to the cheirolepids, a group of conifers often associated with warm and dry conditions. In palynofloras of similar age from central and south Europe, pollen of the Circumpolles group tend to be much more abundant.

The diverse Ladinian spore-pollen flora described above indicates a generally warm and dry climate, but the diversity and preservation suggest a change towards more humid conditions favouring preservation of palynomorphs during this interval. In Germany and Poland the uppermost Ladinian, known as the Lettenkeuper, is interpreted as reflecting more humid conditions. It seems plausible that the palynofloras recorded in this study reflect the same change to more humid conditions.

\section{Conclusions}

The recorded Ladinian palynofloras from the Maglarp-C member in southern Sweden, the lowermost Oddesund Formation in Denmark, and from the middle Skagerrak Formation in both Denmark and Norway, enable correlation between these units in the otherwise poorly dated Triassic succession in the Norwegian-Danish Basin. The fact that the palynofloral assemblages are recognisable even in ditch cutting material of exploration wells makes them very useful markers. The palynoflora contains many elements indicating a warm and dry climate, and deposition in fresh to brackish water in coastal environments. The preservation of the palynoflora probably reflects a climatic event with a change to more humid conditions, similar to that recorded in northern and central Europe.

\section{Acknowledgement}

We thank Talisman Energy Norway A/S for allowing us to publish results from the Norwegian wells.

\section{References}

Bertelsen, F. 1975: Triassic palynology and stratigraphy of some Danish North Sea boreholes. Danmarks Geologiske Undersøgelse Årbog 1974 , 17-32.

de Graziansky, P.-C., Hardenbol, J., Jacquin, T. \& Vail, P.R. (eds) 1998: Mesozoic and Cenozoic sequence stratigraphy of European basins. Society for Sedimentary Geology (SEPM) Special Publication 60, 786 pp.

Kozur, H. 1974: Biostratigraphie der germanischen Mitteltrias. Freiberger Forschungshefte C280 Paläontologie, Teil I, II \& Anlagen, 56 pp. + 71 pp.

Michelsen, O. \& Clausen, O.R. 2002: Detailed stratigraphic subdivision and regional correlation of the southern Danish Triassic succession. Marine and Petroleum Geology 19, 563-587.

Nielsen, L.H. 2003: Late Triassic - Jurassic development of the Danish Basin and the Fennoscandian Border Zone, southern Scandinavia. In: Ineson, J.R. \& Surlyk, F. (eds): The Jurassic of Denmark and Greenland. Geological Survey of Denmark and Greenland Bulletin 1, 459-526.

Petersen, H.I., Nielsen, L.H., Bojesen-Koefoed, J.A., Mathiesen, A. \& Dalhoff, F. 2008: Evaluation of the quality, thermal maturity and distribution of potential source rocks in the Danish part of the Norwegian-Danish Basin. Geological Survey of Denmark and Greenland Bulletin 16, 66 pp.

Retallack, G.J. 1975: The life and times of a Triassic lycopod. Alcheringa 1, 3-29.

Schulz, E., \& Heunisch, C. 2005: Palynostratigraphische Gliederungsmöglichkeiten des deutschen Keupers. Courier Forschungsinstitut Senckenberg 253, 43-49.

\footnotetext{
Authors' addresses

S.L., J.H.V., L.H.N., S.P., \& K.D., Geological Survey of Denmark and Greenland, Øster Voldgade 10, DK-1350 Copenhagen K, Denmark. E-mail: sli@geus.dk M.E., Geological Survey of Sweden, Kiliansgatan 10, S-223 50 Lund, Sweden.
} 